\title{
TRANSFORMATION OF GEORGIA'S TRADE POLICY STRATEGY: FROM FRAILTY TO SUSTAINABILITY
}

\author{
Giga Abuseridze ${ }^{1}$, Mariana Petrova ${ }^{2,3}$, Vitolds Zahars $^{4}$, Vladas Tumalavičius ${ }^{5}$ \\ ${ }^{1}$ Riga Stradins University, Riga, Latvia \\ ${ }^{2}$ St. Cyril and St. Methodius University of Veliko Tarnovo, Veliko Tarnovo, Bulgaria \\ ${ }^{3}$ ISMA University, Riga, Latvia \\ ${ }^{4}$ Daugavpils University, Daugavpils, Latvia \\ ${ }^{5}$ General Jonas Žemaitis Military Academy of Lithuania, Vilnius, Lithuania
}

e-mails: ${ }^{1}$ giga.abuseridze@ @rsu.lv, ${ }^{2,3}$ m.petrova@ts.uni-vt.bg, ${ }^{4}$ vitolds.zahars@inbox.lv, ${ }^{5}$ vladas.tumalavicius@lka.lt

Received:20 December 2021 Accepted:29 December 2021 Online Published:30 January 2022

\begin{abstract}
The following article reviews the trade policies and practices of Georgia as well as Georgia-WTO relationship. The authors focus on Georgia's recent economic performance, including Association Agreement (AA) with the European Union that contributed powerfully to stabilising Georgia's trade legislation and reinforcing domestic economic reform. The Association Agreement between Georgia and the European Union and its member States aims at Georgia's gradual economic integration into the EU Internal Market, through the establishment of the DCFTA, which should provide for far-reaching market access based on sustained and regulatory approximation.

The study reveals the importance of the World Trade Organization, main trade agreements and arrangements with Georgia as a developing country. It demonstrates that effective trade stabilization in the WTO can be achieved by the implementation of specific WTO's regulations on trade, economic and legal spheres.

One of the reasons for the special success of the WTO is systemic exceptions for developed countries and states with special needs (country like Georgia) that contributes to the development of international trade through progressive liberalization and the comparative advantage of the states when carrying out trade.

The example of Georgia shows very well that so far the country has not been able to actively apply all the advantages that can be used within the framework of international or regional organizations, at least for the simple reason that the country does not possess the appropriate infrastructure for bringing innovative products to foreign markets, and thus accumulate more economic wealth.

This case study evidences and confirms that while the accession process to the WTO is challenging per se, it is part of a process of domestic reforms that triggers growth and economic benefits.
\end{abstract}

Keywords: Association Agreement, European Union, Deep and Comprehensive Free Trade Agreement, Foreign Direct Investment, World Trade Organization

JEL classification: F13, F02, K33

Citation:

Abuseridze, G., Petrova, M., Zahars, V., Tumalavičius, V. (2022). Transformation of Georgia’s trade policy strategy: from frailty to sustainability. Access to science, business, innovation in digital economy, ACCESS Press, 3(1): 43-52. https://doi.org/10.46656/access.2022.3.1(4) 


\section{INTRODUCTION}

Trade diplomacy is a prominent issue in almost every country's foreign relations. Georgia, as a part of the civilized world, despite the challenges, is involved in the process of economic transformation. Georgia has made sweeping economic reforms during the last years, developing from a nearly failed state in 2003 to a relatively well-functioning market economy in 2019. Georgia has achieved significant results in terms of curbing low-level corruption, streamlining an inefficient administration, eliminating unnecessary licensing requirements, improving the State's tax collection capabilities, liberalizing its trade regime and generally improving Georgia's attractiveness based on ease of doing business. However, progress has been coupled with shortcomings, particularly in the aftermath of the 2008 financial crisis and the war with the Russian Federation.

At the same time, it is notable that following parliamentary and presidential elections in 2012 and 2013 respectively, a peaceful transfer of power took place for the first time in Georgia's modern history. Since 2012, the Government has broadly continued the previous Government's low-regulation, low-tax free market policies while modestly increasing social spending. Also, the Russian Federation lifted its embargo on Georgian wine, mineral water and certain agricultural goods in 2013 that had been in place since 2006. The Russian embargo made it clear that modern challenges in Georgia's trade relations required greater diversification in order to avoid and prevent potential threats in the future. Following the signing of the Deep and Comprehensive Free Trade Agreement (DCFTA) with the European Union, the export of Georgian products and their competitiveness in the world market became particularly important (Abuseridze, 2020).

Given this context, the article raises several questions on economic transformation of Georgia. What are the benefits of Georgia's WTO membership for the EU and Georgian businesses?

In order to answer these and many similar questions the authors will analyze Georgia's main trade agreements arrangements and other important issues.

\section{Main trade Agreements and Arrangements}

Trade liberalization is one of the key objectives on Georgia's economic policy agenda. After Georgia's integration into the WTO, country undertook a large number of reform initiatives targeted at streamlining, liberalization and simplification of trade regulations and their implementation. Following the Rose Revolution in 2003, the Georgian government increased efforts to reduce corruption in public and private sector and sought to meet international standards. These efforts resulted in significant improvements in Georgia's ranking in the World Bank's Doing Business Survey. Between 2006 and 2019, Georgia jumped from $112^{\text {th }}$ place in the overall rankings for ease of doing business to the 6th (World bank, 2019).

One of the strategic initiatives is to develop Georgia's trade-transit function. The framework has been established that is intended to allow investors to conduct processing activities in Georgia in connection with the transit of goods without being subject to Georgian taxes (Georgian National Investment Agency, 2021).

As regards main trade agreements and arrangements - after gaining independence in 1991, Georgia's economy collapsed and it is the only country in the South Caucasus and Central Asia that has not reached its 
pre-independence real GDP level; as of 2013, Georgia's GDP was estimated to be $80 \%$ of its 1990 levels (World Bank, 2014). Georgia's trade policy review in 2009 showed how since the Rose Revolution in 2003, the Government established a structural reform programme that aimed, inter alia, to liberalize trade, improve infrastructure, upgrade the business environment, strengthen public finances and combat corruption. As a result, growth accelerated to an average rate of 9.4\% during 2004-2007. This acceleration was halted by the twin shocks in 2008: the conflict with the Russian Federation and the global financial crisis. The impact of the crises was relatively short-lived and the economy rebounded in 2010-2013, with growth averaging 5.8\%. Over the past decade or so, GDP per capita increased from US\$ 920 in 2003 to US\$3,680.8 in 2014, although Georgia's overall impressive growth performance was not matched by commensurate declines in unemployment and poverty.

At the start of the review period (2009 to 2020), average annual real GDP growth rebounded from $-3.7 \%$ in 2009 to an average of $5.8 \%$ in 2010-2013. GDP per capita increased by over half to reach US\$3,681 in 2014, although Georgia's overall impressive growth performance was not matched by commensurate declines in unemployment and poverty. While the current account deficit has narrowed from a peak of $22 \%$ of GDP in 2008 , it has remained significant at 10-13\% of GDP during 2010-12. Real GDP growth slowed significantly to $3.3 \%$ in 2013 from $6.4 \%$ in 2012, reflecting slower global growth, weak domestic demand and economic deceleration related to the political transition that prompted investor caution. Growth for 2014 recovered to $4.8 \%$ (just below the Government's 5\% target) but the depressed economies of Georgia's major trading partners are expected to halve growth to around 2\% in 2015 (International Monetary Fund, 2018) . The positive dynamics of growth continued for the next 5 years (2015-2020) but due to the COVID-19 pandemic Georgia's GDP Declined by $5.8 \%$ in first half of 2020 .

The key event of this review period occurred in June 2014, when Georgia signed the Association Agreement (AA) with the European Union. The AA includes a Deep and Comprehensive Free Trade Area (DCFTA), which plans to enhance Georgia's trade prospects and boost economic growth by bringing its legislation closer to that of the EU. It also removes the existing barriers on the trade of goods and services with the EU. Georgian products have to meet certain EU requirements not only for export, but also when consumed within the country.

The authors explain that this study does not aim to explore the hierarchy of legal norms proceeding on the relations between the WTO and EU or their interdependence; rather it focuses on the entries in the Association Agreement between Georgia and the European Union which refer to Georgia's compliance with the WTO obligations and their superior power.

In accordance with Article 1 of the Association Agreement, the goal is to achieve gradual economic integration of Georgia into the EU internal market that will ensure reliable market access based on sustainable and comprehensive regulatory convergence of rights and obligations arising from WTO membership. The signing of the Association Agreement with the EU sends a very positive message to the markets, and helps to promote exports to the area from 2014-2019 (Trade/economic structure and trends see below Figure 1.) onwards, which creates a practical framework for achieving EU-Georgia political association and trade 
integration. Moreover, the authors believe that the tools such as the DCFTA offer the EU an opportunity to spread its sphere of influence to its east, including the Caucasus region. This remains a sensitive area for Europe as it presently depends on Russia to meet its energy needs. Deeply cognizant of this, Russia uses its energy resources as a political bargaining chip. Indeed, as the South Caucasus region belongs to the energyrich Caspian region, it is advantageous in the long-term for Europe to diversify its energy resources and energy partners. The authors argue, that this perspective adds extra stimulus to the development of Georgia into a trade transit corridor.
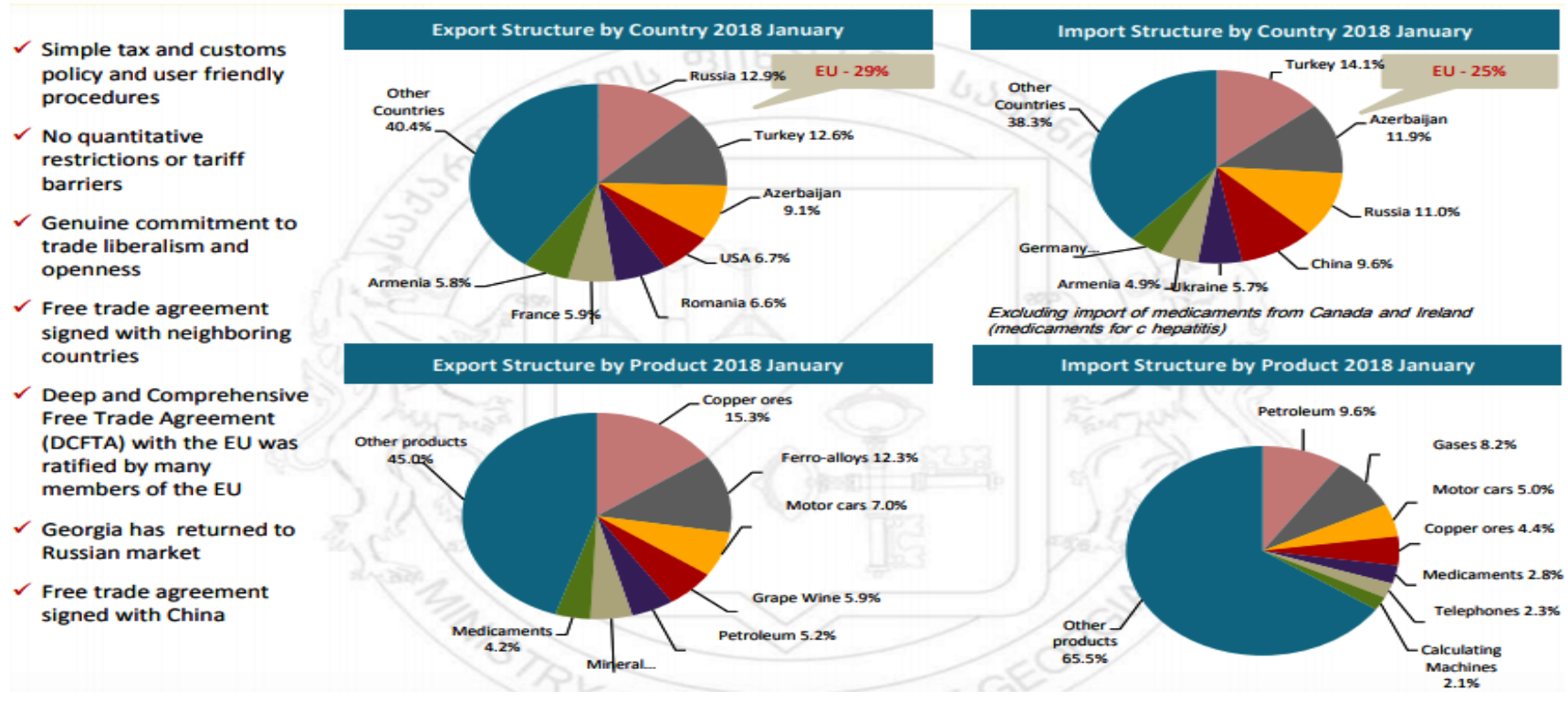

Figure 1. Trade/Economic Structure and Trends*

* Liberalized trade, diverse partners, significant and growing network of free trade agreements.

Source: Ministry of Finance of Georgia (2018). Georgia - The outlook.

National Statistics Office of Georgia online information; IMF, International Financial Statistics online information.

As a member of the WTO since 2000, Georgia grants MFN treatment to all WTO Members. Georgia is an observer to the Government Procurement Agreement. Georgia has GSP arrangements with the United States (temporarily terminated), Japan, Canada, Switzerland and Norway. In 2009, Georgia terminated its membership of the CIS organization but has maintained bilateral FTAs with eight CIS countries and also has an FTA with Turkey, a Trade and Investment Framework Agreement with the United States. Georgia and China are completing a joint feasibility study on a possible Georgia-China Free Trade Agreement and have also signed a Memorandum of Understanding on strengthening cooperation for the Silk Road Economic Belt initiative.

The Ministry of Economy and Sustainable Development is the executive authority which determines, implements and coordinates state policy in the field of trade. In the ministry, the Department for Foreign Trade and International Economic Relations is exclusively involved in the formulation of foreign trade policy. As part of its daily functions, the department closely cooperates with several trade-related bodies under the 
ministry and collaborates with other relevant entities, including in the private sector. The Department implements the mandatory notification submission procedures to the WTO. The main instrument regulating foreign trade in Georgia is the revised 2011 Tax Code of Georgia, which defines objects subject to import taxation, customs regimes and procedures as well the exemption of certain goods from import duties. Legislative amendments have taken place in several trade-related areas. Georgia has continued to develop its national quality infrastructure in accordance with international and EU practices. Its TBT strategy stipulates that Georgia refrains from adopting national standards in the areas where relevant international standards exist. About $98 \%$ of all standards adopted in Georgia are international or European standards (World Trade Organization, 1999).

\section{Georgia's Accession Process and the Implementation of its Commitment}

The process of obtaining Membership of the WTO is complex and implies many challenges for the countries wanting to join and hence the long average duration. Once that goal is achieved, the practice shows that WTO membership creates significant new opportunities. This perhaps best explains why, since the WTO was created in 1995, a total of some 36 countries have taken the initiative to join the WTO and successfully completed the accession process nearly two dozen more are presently negotiating their accession.

Georgia was one of the countries that shortly after becoming an independent state launched the process of joining the WTO in July 1996. This decision was largely driven by the new trade opportunities that WTO membership offers and the decision taken to undertake the necessary reforms with a view of aligning domestic policies with international standards and requirements. Following 4 years negotiations, it obtained the green light from the WTO members, leading to the formal ratification by Georgia's Parliament in May 2000, thus freeing the way to become the WTO's 137th member on 14 June 2000. Georgia was the fourth former Soviet Republic joining the WTO after the Kyrgyz Republic, Latvia and Estonia (WTO Secretariat, 2015). In the early years of the transition, many countries in the region started to adopt liberal import policies, in many cases largely driven by willingness and policy objectives to join the WTO. The dismantling of the Soviet Bloc brought economic chaos and a collapse of trade flows, which compelled countries in Central and Eastern Europe to begin to reintegrate into the global economy. Georgia, as one of the three Caucasus countries, was no exception and determined to undertake the domestic reforms and adjustments to abide by the market-based principles. The objectives of trade liberalization, market opening and ensuring transparency were and still are at the heart of Georgia's reform policies (Broadman, H., G. 2005).

With trade being considered the main driver of economic growth, the main objectives of Georgia's trade policy are defined as follows:

1. Integration into the world economy, including the implementation of WTO membership obligations and obligations under other international agreements; 
2. Trade policy liberalization, including simplification of export and import procedures and tariff and non-tariff regulation;

3. Diversification of trade relations by establishing preferential regimes with main trade and regional trade partners;

4. Enhancement of transparency in the policy-making.

In order to pursue these objectives and as a new and Recently Acceded Member (RAM) of the WTO, the main challenges for Georgia consisted of continuing the reform process initiated during the accession process. It is considered to be the only way to take advantage of the benefits that WTO membership offers and to operate the system. The domestic reform process included a broad range of measures aimed at reducing transaction costs, easing business transactions, reviewing tax laws and regulations and enhancing transparency with a view of attracting foreign direct investment (FDI). In order to build such human and institutional capacity, support was provided both by the WTO Secretariat and bilateral donors (Smeets, M. 2013). Georgia's main reform initiatives target streamlining, liberalization and simplification of trade regulations and their implementation. All measures are geared towards enhancing competition, encouraging and facilitating trade, easing customs procedures, lowering import duties and reducing the incidence of non-tariff measures.

Fiscal and tax reforms: Some of the main reforms that were put into effect included the corporate income tax reform, enhancing easiness of tax compliance, enhancing stock exchange activities, the development of local capital market, a reform of the pension scheme, based on a private pension system, the introduction of transparent and efficient public-private partnership (PPP) framework, the creation of a public investment management framework, which should lead to an improved efficiency of state projects, stimulating private savings, strengthening the public trust in the financial system, enhancing the transparency and financial accountability and strengthening the protection of shareholder rights (European Commission, 2021).

More specifically with regard to tax and fiscal legislation, the Georgian tax system was simplified and tax rates were reduced. An easily administered, flat, and simple tax system was introduced. The number of different taxation schemes was reduced from 21 to only 6 types of taxes. These include corporate income tax, personal income tax, property tax and indirect taxes such as VAT, excise, and import duties. A new tax code entered into force on January 1, 2011, which incorporates both the tax and customs codes. Further improvements and innovations included the introduction of the status of micro, small business, the establishment of a Tax Ombudsmen, and the principle of good faith. All measures further strengthened the principles of transparency and accountability. Furthermore, the Georgian business licensing system was modernized and simplified and 'unnecessary' regulations, which often turned out to be a source of corruption were abolished. The number of licenses and permits necessary for doing business was reduced by almost $85 \%$ and the "single window" and "Silence is Consent" principles were introduced.

Hence, the author can answer the question: What are the benefits of Georgia's WTO membership for the EU and Georgian businesses? 
Accession of WTO contributed powerfully to stabilising Georgia's trade legislation and reinforcing domestic economic reform and therefore increasing the stability and predictability for EU businessmen exporting to, or investing in, Georgia. It is believed that Georgia's medium-term growth prospects depend on a number of factors, including its ability to take advantage of the free trade agreement with the EU. Georgia has conducted major structural reforms in order to achieve all its key objectives, i.e. the integration into the world economy, including the implementation of WTO membership obligations and obligations under other international agreements, trade policy liberalization, including simplification of export and import procedures and tariff and nontariff regulation, diversification of trade relations by establishing preferential regimes with main trade and regional trade partners and finally enhancing of transparency in the policy-making. These objectives for the major part continue to have the attention of the government and in many ways are considered as work in progress. Through its active participation in international trade, Georgia aims to diversify exports and benefit from MFN treatment granted by WTO members. Today Georgia is an active Member in the WTO, and has made substantive inputs in the negotiations of the DDA, including with specific text and negotiating proposals on technically complex issues with a view of directly serving its economic and trade interests at the multilateral level. It will actively continue doing so in pursuit of its economic development policy objectives. The WTO is described foremost as a trade-economic partnership-type institution with 164 member states. This is also advantage for Georgian exporters who will be better able to ensure their rights in doing business worldwide.

However, the authors argue, that there is a gap in the text of the Association Agreement in regard of the WTO; in particular, the Organization is referred to rather inconsistently and it seems that there is no unified vision on the name of the organization. The author believes, that the state should decide how to denominate such an important organization in the official documents, based on common practice of using terms of legal acts.

\section{CONCLUSION}

The analysis of the process of Georgia's economic integration into the EU leads to the conclusion that in this respect Georgia has no enforcement problem ensuing from concomitant obligations for one reason: the text of Georgia's Association Agreement repeatedly stresses respect for the WTO principles and treaties and their preferential legal force in the case of collusive norms.

The authors believe that one of the reasons for the special success of the WTO is systemic exceptions for developed countries and states with special needs that contributes to the development of international trade through progressive liberalization and the comparative advantage of the states when carrying out trade. This is especially important for a country like Georgia.

According to the authors, the example of Georgia shows very well that so far the country has not been able to actively apply all the advantages that can be used within the framework of international or regional 
organizations, at least for the simple reason that the country does not possess the appropriate infrastructure for bringing innovative products to foreign markets, and thus accumulate more economic wealth.

The authors claim that it is necessary for the state to take responsibility for the relevant procedures and promote the production of services or products in the country, in which the country will take its niche in the international space.

Finally, and to conclude, this case study evidences and confirms that while the accession process to the WTO is challenging per se, it is part of a process of domestic reforms that triggers growth and economic benefits. WTO's membership doesn't automatically lead to economic gains, which can only be obtained through hard work, a strong and continued commitment to undertake domestic reforms and put the right policy conditions in place to trade and attract FDI. It requires a vision, a strategy and a clear understanding of the country's potential and the political will and determination to put all the elements and conditions in place to create synergies.

Author Contributions: Conceptualization, G.A.; methodology, G.A.; formal analysis, G.A., V.Z; investigation, G.A.; project administration, G.A., M.P.; data curation, M.P; resources, V.T., V.Z., M.P.; supervision, G.A.; validation, G.A., V.Z; writing—original draft preparation, G.A; writing—review and editing, V.Z., V.T.

All authors have read and agreed to the published version of the manuscript.

\section{Conflict of interests}

The authors declare no conflict of interest.

\section{References}

Abuseridze, G (2020). Trade War: Georgia vs. Russia. Electronic Scientific Journal of Law Socrates. January 2020; SOCRATES Rīgas Stradina universitātes Juridiskās fakultātes elektroniskais juridisko zinātnisko rakstu žurnāls / SOCRATES Rīga Stradinš University Faculty of Law Electronic Scientific Journal of Law 3(18):147-154. DOI: $10.25143 /$ socr.18.2020.3.147-154

Baklanova, O., Petrova, M., Koval, V. (2020). Institutional transmission in economic development, Ikonomicheski Izsledvania (Economic Studies), 29(1), pp. 68-91

Broadman, Harry G. (2005) From Disintegration to Reintegration: Eastern Europe and the Former Soviet Union in International Trade. Washington, DC: World Bank. C) World Bank. https://openknowledge.worldbank.org/handle/10986/7511 $\quad$ License: $\quad$ CC $\quad$ BY $\quad 3.0 \quad$ IGO.// http://hdl.handle.net/10986/7511

European Commission (2021). EU-Georgia Deep and Comprehensive Free Trade Area (DCFTA). https://trade.ec.europa.eu/access-to-markets/en/content/eu-georgia-deep-and-comprehensive-free-trade-area

Georgian National Investment Agency (2021). Favorable Tax Regimes in the Country. https://www.pwc.com/ge/en/assets/pdf/june-2021/DBG\%202021_as\%20of\%2031\%20March\%202021.pdf

International Monetary Fund (2018). IMF Country Report. https://www.imf.org/external/pubs/ft/ar/2018/eng/

Matyushenko, I., Hlibko, S., Petrova, M., Khanova, O., Loktionova, M., Trofimchenko, K. (2021). Assessment of technological competitiveness of Ukraine in terms of association with the EU. Ikonomicheski Izsledvania (Economic Studies), ISSN 02053292, 30(7), pp. 148-176 
Matyushenko, I., Hlibko, S., Petrova, M. M., Pasmor, M. S., \& Loktionova, M. (2020). Assessment of the development of foreign trade in high-tech production of Ukraine under the association with the EU. Business, Management and Education, 18(1), 157-182. https://doi.org/10.3846/bme.2020.11578

Ministry of Finance of Georgia (2018). Georgia - The outlook. https://www.mof.ge/images/File/Georgia-TheOutlook_ENG_Apr-2018.pdf

Smeets, M. (2013). Trade Capacity Building in the WTO: Main Achievements since Doha and Key Challenges. Journal of World Trade. Volume 47, Issue 5, pp.1047-1090, https://kluwerlawonline.com/journalarticle/ Journal+of+World+Trade/47.5/TRAD2013035

World Bank (2018). Doing Business 2019: A Year of Record Reforms, Rising Influence. https://www.worldbank.org/en/news/immersive-story/2018/10/31/doing-business-2019-a-year-of-record-reformsrising-influence

World Bank (2014). Annual Report. https://www.worldbank.org/content/dam/Worldbank/AR14_OperationalHigh lights.pdf

WTO Secretariat (2015). Trade Policy Review, Report by Georgia, WT/TPR/G/328. (15-5924). Page: 1/13. https://www.wto.org/english/tratop_e/tpr_e/s328_e.pdf

World Trade Organization (1999). WTO Report of the Working Party on the Accession of Georgia to the World Trade Organization WT/ACC/GEO/31. https://docs.wto.org/dol2fe/Pages/SS/directdoc.aspx?filename=Q:/WT/ACC/ GEO31.pdf\&Open=True

\section{About the authors}
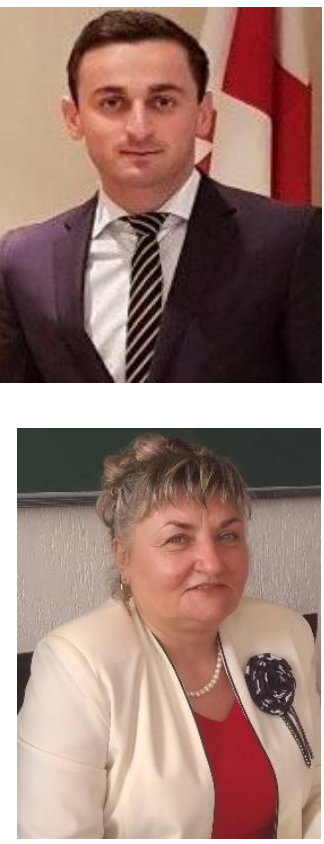

\section{Giga ABUSERIDZE}

Ph.D in Law, researcher and lecturer at Riga Staradins University since 2015.

His research profile is focused on international trade issues, transformation of trade system, WTO, DCFTA etc. One of his main areas of interest is also Law and Diplomacy. He is the author 25 scientific papers (also published in Scopus and WoS), several policy papers and international research projects.

ORCID ID: https://orcid.org/0000-0003-2868-8719

\section{Mariana PETROVA}

Professor, PhD in Physics and Mathematics, assoc.prof. St. Cyril and St. Methodius University of Veliko Tarnovo, Bulgaria; Professor Economics and Management in Department of Management, ISMA University, Riga, Latvia.

Research interests: management of IT processes, project and services, business administration, modern information systems and innovations, knowledge economy, sustainable development.

ORCID ID: https://orcid.org/0000-0003-1531-4312 

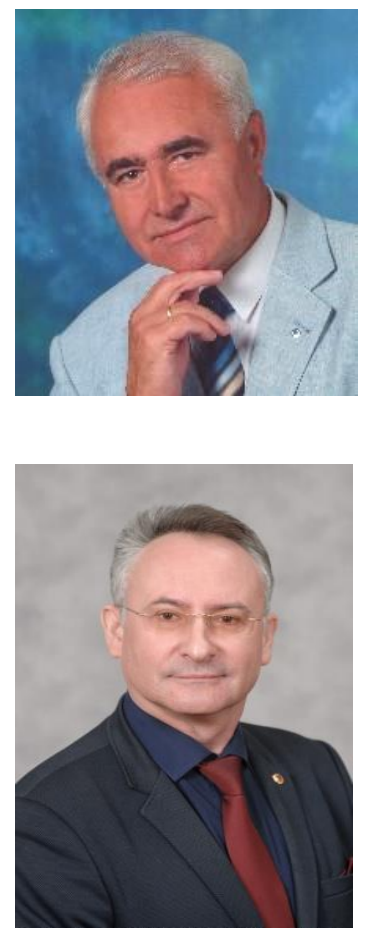

\section{Vitolds ZAHARS}

Professor, Dr. iur., Head of Law Department Faculty of Social Sciences Daugavpils University, Daugavpils, Latvia. He is the author of 14 books (6 monographs and 8 text books) and more than 100 scientific articles.

Research interests: Criminal Policy, Criminal Law, Crime Determinants, Penology, European Human Rights, Globalisation

ORCID ID: https://orcid.org/0000-0003-1100-0519

\section{Vladas TUMALAVIČIUS}

Dr. iur. Lecturer at General Jonas Žemaitis Military Academy of Lithuania, Research Group for Security Institutions Management

Research interests: Legal Regulation of Public Safety and Administration; Issues of National, State and Regional Security and Sustainability; Regional Economics Security.

ORCID ID: https://orcid.org/0000-0002-0811-0074

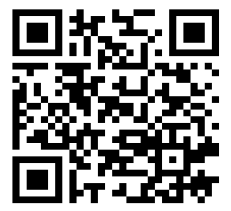

Copyright (C) 2020 by author(s) and ACCESS Publishing Press This work is licensed under the Creative Commons Attribution International License (CC BY) 